\title{
Open Market Repurchase Programs - Evidence from Finland
}

\author{
Kenneth Högholm ${ }^{1} \&$ Victor Högholm ${ }^{1}$ \\ ${ }^{1}$ Department of Finance and Statistics, HANKEN School of Economics, Vaasa, Finland \\ Correspondence: Kenneth Högholm, Department of Finance and Statistics, HANKEN School of Economics, P.O. \\ Box 287, 65101 Vaasa, Finland. E-mail: kenneth.hogholm@hanken.fi
}

Received: September 18, 2017

Accepted: October 12, 2017

Online Published: October 30, 2017

doi:10.5539/ijef.v9n12p13

URL: https://doi.org/10.5539/ijef.v9n12p13

\begin{abstract}
Share repurchase programs have during the past few decades become an important way of distributing cash to shareholders since they are viewed by managers as more flexible than dividends. Open market repurchase authorizations effectively also give managers an option to repurchase shares when they view their stock as undervalued. This study exploits a data set of open market repurchases programs initiated by Finnish stock market listed companies. Finland is unique with regard to the disclosure requirements of open market repurchase programs, which enables an examination of the information content in both the initiation announcement as well as in the announcement of actual repurchases. The study covers all 293 share repurchase programs initiated between 1998 and 2013. The results show a significant positive announcement effect of about 2 percent on the initiation day. The CAAR over a five day event window is also about 1.5 percent (statistically significant). Furthermore, an additional statistically positive effect of 1.5 percent is found on the first repurchase day (about 1.1 percent over a five day event window). The positive announcement effect is larger for announcements regarding initiations of the first or the second repurchase program for a company.
\end{abstract}

Keywords: share repurchase, signaling, asymmetric information, abnormal return, event study

\section{Introduction}

Share repurchase programs have during the past few decades become an important way of distributing cash to shareholders since they are viewed by managers as more flexible than dividends. Hence, e.g., Brav et al. (2005) report that this flexibility is used to increase payouts when good investment projects are scarce, and to decrease the payouts when the company has a need to retain the earnings due to several good investment projects. A company may also initiate a share repurchase program if their stock is perceived to be undervalued (Note 1). Several studies of open market share repurchase programs find that managers seems to be able to time the market (Note 2).

There is a lot of studies, especially focusing on the US market, looking at the announcement effect of open market share repurchase authorizations. A repurchase authorization gives the management team a possibility to acquire shares when they are perceived to be undervalued. If company outsiders believe that insiders are able to better determine the true value of the company, one would expect a positive authorization announcement effect. This is also the case in the US, where an authorization announcement on average yields an abnormal return of approximately $3 \%$ (Note 3 ).

The reported announcement effect is on average much smaller in Europe (Note 4). The institutional setting is, however, different in many European countries compared to the US. It is the Board of Directors that gives the authorization to repurchase shares in the US, while a repurchase program has to be approved by the shareholders' meeting in many European countries. Hence, usually the studies in Europe look at the abnormal return around the stock market release, announcing that the company intends to ask the shareholders' meeting to approve an authorization to repurchase shares. Usually, this authorization is given for a time period of maximum 18 months. However, the authorization is not binding, i.e., the company does not have to buy a single share although the authorization is approved. Therefore, a lot of companies frequently ask the shareholders' meeting for the authorization giving the company a mandate to repurchase shares. Since this behavior is observed by the market, and hence expected, it is understandable that the market response, and the observed stock price reaction, is quite modest to these announcements.

Finland is similar to other countries within the EU, i.e., it is the shareholders' meeting that has to authorize a 
share repurchase program. However, the regulation in Finland regarding the type of information that need to be disclosed in open market share repurchase programs is quite unique. According to the rules of the Stock Exchange, a decisions to use the mandate to repurchase shares must be disclosed immediately. Hence, before a company starts to repurchase shares this initiation announcement must be published. After a waiting period of some days after the initiation announcement the company may actually start to repurchase shares. However, the company does not have to repurchase a single share although the company has published the initiation announcement. If the company decides to actually repurchase shares, the company also have to disclose this actual repurchase activity on a daily basis. Hence, it is also possible to look at the effect on the price of these actual share repurchases.

In this study we look at authorizations of open market share repurchase programs that Finnish stock market listed companies have asked the shareholders' meeting for during the time period January, 1998 to December, 2013 (Note 5). To our knowledge there are very few studies looking at the share repurchase market in Finland. The purpose of this study is twofold. Firstly, we look at the stock market reaction to the initiation announcement of open market share repurchase programs. Secondly, we also look at the market reaction to the announcement that a company actually starts to repurchase shares within a repurchase program.

Studying the stock market reaction of open market share repurchases in Finland is interesting since the disclosure rules in Finland give information to all investors about possible repurchase activity, which may be perceived as valuable information by the investors. Second, since the companies are not obliged to repurchase shares, although they have made an initiation announcement, it is interesting to examine if the actual start of repurchasing also convey valuable information to the investors.

The results show a statistically significant average abnormal return of $2.04 \%$ at the time of the initiation announcement. The announcement effect is higher for repurchase programs initiated for the first or the second time by a company, hence, indicating that the market perceives the information content in these announcements to be more valuable than the information content in announcements from companies that on a regular basis uses repurchase programs. The average abnormal return is also significant and positive on the first repurchase day in a repurchase program, with an average abnormal return of approximately $1.5 \%$. The price effect on the actual first repurchase day is positively correlated with the program being the first for a company, and is negatively correlated to the fraction of shares the company intends to repurchase in the program. The result indicates that the market perceives the actual repurchases as a signal of undervaluation.

The reminder of the paper is organized as follows. Section 2 summarizes the previous research on announcements regarding share repurchase programs. Section 3 describes the methodology and the data, while the empirical results are presented in Section 4. Section 5 concludes the study.

\section{Literature Review}

Companies repurchase their shares for different reasons. Several reasons for why firms use share repurchases have been proposed in the literature. One of the main motives are explained by the signaling of undervaluation, hence, firms repurchase their shares to signal private information that the shares are undervalued. This presupposes information asymmetry between insiders and outsiders of the firm. The more severe the information asymmetry, the more likely the firm will experience undervaluation from time to time. Share repurchases may then act as a credible signal to the market and the stock price adjusts. Hence, there should be a positive reaction from the market to a repurchase announcement (Note 6).

Previous studies do document a positive stock market price reaction to the announcement of an intention to repurchase shares. Empirical results for the US market (see, e.g., Vermaelen, 1981; Comment \& Jarell, 1991; Ikenberry et al., 1995; Stephens \& Weisbach, 1998; Grullon \& Michaely, 2002; and Peyer \& Vermaelen, 2005) show a positive abnormal return of approximately 3\% around the announcement. This is an indication of repurchasing announcements having an information content that is perceived to be valuable by the investors.

Empirical studies of the European repurchase market document a smaller announcement effect than the corresponding announcement effect in the US, with reported excess returns of about $1 \%$ (Rau \& Vermaelen, 2002; Lee, Ejara, \& Gleason, 2010; Andriosopoulos \& Lasfer, 2015). However, due to the regulations of the markets, the shareholders' meeting has to approve the share repurchases. Hence, most European studies focus on the announcement when the firms ask for the shareholders' meeting authorization for a share repurchase program. Since a lot of companies do this more or less every year, it is expected that the market reaction to these announcements is quite small.

There are not many studies looking at the market reaction to the announcement of an actual repurchase activity. 
This because in most countries the companies are not required to disclose their repurchase activity on a daily basis. McNally et al. (2006), Zhang (2005), Skjeltorp and Williams (2004), and Råsbrant (2013) look at the market reaction to actual share repurchases in Canada, Hong Kong, Norway, and Sweden, respectively. They all document a positive abnormal return on the actual repurchase day. McNally et al. (2006) show that repurchase activity support the share price and that the companies that repurchase seem to have timing ability.

Karhunen (2002) is the only study examining the stock market reaction to announcements regarding share repurchase programs in Finland. He looked at 81 authorized share research programs during the time period 1998-2001. He found an average cumulative average abnormal return of $2.78 \%$ for an event window of five days around the initiation announcement, and an average abnormal return of $1.08 \%$ on the first repurchase day.

In Finland, share repurchases were prohibited until September, 1997, when there was a change in the Companies Act enabling public companies to repurchase their own shares. According to the new regulation, the Board of Directors may ask the shareholders' meeting for an authorization to repurchase a specific amount of shares (Note 7). Hence, the actual decision to repurchase shares is taken by the shareholders' meeting. The shareholders, however, give a mandate to the managers to take decisions regarding the timing of the repurchases and the amount of shares that the company actually do repurchase (within the limit set by the shareholders' meeting). The decision is not a firm commitment, i.e., the firm may choose whether to buy shares or not. The authorization given by the shareholders' meeting has a duration of maximum 18 months, or until a new shareholders' meeting replaces the authorization with a new one. The maximum amount of treasury stock the company may hold at any time is $10 \%$ of the shares in the company (Note 8 ).

When the shareholders' meeting has approved the share repurchase program, the company may choose to start the repurchase program at any time. However, before starting the repurchase program, the company has to make a public initiation announcement that it intends to start repurchasing shares. In the announcement, the company must declare how many shares they intend to buy and when they intend to start (there is a minimum waiting time of seven days between the intention announcement and when the actual repurchase may start). However, although the company has made an initiation announcement that they intend to repurchase, e.g., five percent of the outstanding shares, this is still not a binding announcement, hence, the company may choose to repurchase less or not at all.

When the company actually starts to repurchase shares it has to make a public announcement each repurchase day stating the number of shares bought, the minimum and maximum price paid during the day, and the average price paid.

We expect to find, in line with empirical findings for other markets, a positive stock market reaction to an initiation announcement that the company intends to start repurchasing shares. However, since the announcement is not a firm commitment, it is a costless signal that is easy to mimic also for low quality companies. Hence, only an actual repurchase will in full reveal the information in the signal. Therefore, we also expect to find a positive announcement effect for the first actual repurchase trading day. Therefore, our first hypotheses are:

H1: The initiation announcement to repurchase shares will result in a positive stock market reaction

$\mathrm{H} 2$ : The announcement of the first actual repurchase of shares will result in a positive stock market reaction.

If a share repurchase announcement can be view as a signal of undervaluation, and, hence, reduce the information asymmetry, then this signal will carry a higher information content for a company that repurchases for the first time compared to a company that has a history of yearly repurchases. Hence, our third hypothesis is:

H3: The announcement effect is larger for companies that enter the repurchase market for the first or the second time.

The repurchase signal will be more costly to mimic the larger the fraction of shares the company intends to repurchase. Hence, we expect that the larger the repurchase fraction, the larger the market reaction. However, this can be view as a weak signal, since the companies are not committed to repurchase the amount stated in the initiation announcement, i.e., they can buy substantially less the intended repurchase fraction. Our fourth hypothesis is:

H4: The larger the fraction of shares the company intends to repurchase, the larger the stock market reaction.

Regarding the stock market reaction to the announcement of the start of actual repurchases, we expect the initiation effect to carry forward, i.e., the higher the initiation announcement effect, the larger the announcement effect of the start of actual repurchases. We also argue that there may be a larger announcement effect for 
announcements where the company waits for an optimal time to start to repurchase (assuming the companies possess timing ability) compared to a case where the company starts to repurchase immediately after the seven days waiting period. Hence, our fifth and sixth hypothesis is:

H5: The announcement effect for starting to actually repurchase shares is larger the larger the initiation announcement effect.

H6: There is a positive relationship between the announcement effect of starting to repurchase shares and the duration between the initiation announcement and the first repurchase day.

Finally, we also include a time period dummy to capture any difference in the announcement effect before and after the change in regulations regarding the amount of shares a company can repurchase.

\section{Methodology and Data}

We study the short term initiation announcement effect as well as the short term announcement effect of the first actual repurchase in a program. We also investigate several factors that may explain the stock market reaction to the announcement. We measure the announcement effect as the sum of the daily average abnormal returns (Note 9) (CAAR) over different windows around the announcement day (Note 10), with a total event window of 41 days, 20 days prior to and 20 days after the event day. We also study alternative event windows before and after the announcement day to capture any effect of a price run-up before the event, or a possible value readjustment after the announcement day. The daily abnormal return (AR) is calculated as the difference between the actual return and the expected return:

$$
A R_{i t}=R_{i t}-E(R)_{i t}
$$

where $A R_{i t}$ is the abnormal return, $R_{i t}$ is the actual return, and $E(R)_{i t}$ the expected return. The expected return is calculated using the market model. We use the value-weighted OMX Helsinki as a proxy for the market portfolio. The parameters in the market model are estimated using a window of 241 days, starting 300 days and ending 60 days prior to the event day.

To further study the market reaction to the announcement, we regress the short term abnormal return on several explanatory factors with respect to the characteristics of the repurchase program.

In this study we look at authorizations of open market share repurchase programs that Finnish stock market listed companies have asked the shareholders' meeting for during the time period January, 1998 to December, 2013. The information of the programs were collected from notice of the Annual General Meeting. Information about the initiation announcement (to use the authorization to repurchase shares) were collected from stock exchange releases and from companies' homepages.

Data of actual open market share repurchases were collected from published announcements on NASDAQ OMX Helsinki. The data included in the announcements are the name of the repurchasing firm, the date of the transaction, the total number of shares repurchased, the total cost, and the average repurchase price/share.

Table 1 gives the descriptive statistics for open market share repurchase programs in Finland during the time period 1998-2013. In total, there were 985 share repurchase programs authorized during this period. The average size of the authorized repurchase program was $6.24 \%$ of the total number of outstanding shares. However, almost all authorizations before 2005 are for $5 \%$ of the outstanding shares, i.e., the maximum number of shares that the company is allowed to keep. After 2005 the authorization amount increased, but was on average well below the new maximum of $10 \%$.

Table 1. Descriptive statistics for open market repurchase programs in Finland

\begin{tabular}{ccccccc}
\hline Year & Authoriz & Authoriz\% & Initiation & Initiation \% & Repurchase & Repurchase \% \\
\hline 1998 & 16 & $4,99 \%$ & 9 & $4,7 \%$ & 8 & $3,37 \%$ \\
1999 & 25 & $4,66 \%$ & 15 & $4,0 \%$ & 14 & $2,28 \%$ \\
2000 & 43 & $4,54 \%$ & 21 & $3,7 \%$ & 19 & $2,18 \%$ \\
2001 & 56 & $4,79 \%$ & 30 & $4,2 \%$ & 24 & $1,55 \%$ \\
2002 & 58 & $4,88 \%$ & 27 & $4,8 \%$ & 25 & $1,93 \%$ \\
2003 & 53 & $5,00 \%$ & 14 & $4,6 \%$ & 12 & $2,75 \%$ \\
2004 & 55 & $4,90 \%$ & 14 & $3,7 \%$ & 14 & $2,33 \%$ \\
2005 & 63 & $6,00 \%$ & 20 & $4,9 \%$ & 20 & $1,73 \%$ \\
2006 & 63 & $7,89 \%$ & 19 & $4,9 \%$ & 18 & $1,11 \%$ \\
2007 & 69 & $7,15 \%$ & 26 & $4,2 \%$ & 19 & $1,70 \%$ \\
\hline
\end{tabular}




\begin{tabular}{|c|c|c|c|c|c|c|}
\hline 2008 & 78 & $8,22 \%$ & 32 & $4,7 \%$ & 25 & $1,05 \%$ \\
\hline 2009 & 79 & $7,93 \%$ & 17 & $4,8 \%$ & 12 & $0,99 \%$ \\
\hline 2010 & 83 & $7,19 \%$ & 19 & $4,3 \%$ & 11 & $0,48 \%$ \\
\hline 2011 & 79 & $7,41 \%$ & 15 & $4,4 \%$ & 9 & $0,92 \%$ \\
\hline 2012 & 82 & $7,47 \%$ & 10 & $2,5 \%$ & 7 & $0,62 \%$ \\
\hline 2013 & 83 & $6,05 \%$ & 5 & $4,4 \%$ & 1 & $0,13 \%$ \\
\hline Total & 985 & $6,24 \%$ & 293 & $4,3 \%$ & 238 & $1,65 \%$ \\
\hline
\end{tabular}

Note. The table provides information about open market repurchase programs in Finland initiated during the time period Jan 1998-Dec 2013. Authoriz is the number of companies that asked for authorization from the shareholders meeting for a repurchase program. Authoriz\% is the mean fraction of shares in the authorization. Initiation and initiation\% is the number of initiation announcements and the mean fraction of shares in the initiation announcement, respectively. Repurchase and repurchase $\%$ is the number of programs actually executed and the mean fraction of shares actually repurchased in the programs, respectively.

When a company decides to utilize a repurchase authorization, the information must be publicly disclosed immediately. This initiation announcement must include information about the maximum number of shares the company intends to repurchase. Only about $30 \%$ of authorizations actually lead to an initiation announcement, indicating that most of the companies asked the shareholders' meeting for authorization although they never intended to repurchase shares. The total number of initiation announcements is 293 , while the average fraction sought is $4.3 \%$ of the shares. The yearly average is about the same before and after the change in the regulations in year 2005. Only 238 companies also actually repurchased shares after the initiation announcement, with an average fraction of shares acquired significantly less than the fraction of shares sought. In the mean repurchase program, $1.65 \%$ of the shares were actually bought. The fraction of shares bought is decreasing during the time period.

Table 2 reports the number of repurchase days in the repurchase programs. The mean duration between the initiation announcement and the first repurchase day is 33 days (a median of 11 days) (Note 11). The mean duration of a repurchase program was 114 days (median 84 days), while the average number of repurchasing days was 42 (median 27 days).

Table 2. Characteristics of open market repurchase programs in Finland

\begin{tabular}{cccc}
\hline Year & Waiting time & Duration & Repo days \\
\hline 1998 & 20 & 124 & 43 \\
1999 & 22 & 120 & 52 \\
2000 & 34 & 172 & 70 \\
2001 & 18 & 158 & 51 \\
2002 & 40 & 118 & 47 \\
2003 & 21 & 136 & 47 \\
2004 & 14 & 129 & 33 \\
2005 & 35 & 101 & 42 \\
2006 & 38 & 114 & 30 \\
2007 & 35 & 81 & 39 \\
2008 & 55 & 75 & 35 \\
2009 & 38 & 80 & 26 \\
2010 & 32 & 79 & 26 \\
2011 & 35 & 91 & 30 \\
2012 & 56 & 106 & 38 \\
2013 & 18 & 57 & 27 \\
Totalt & $\mathbf{3 3}$ & $\mathbf{1 1 4}$ & $\mathbf{4 2}$ \\
\hline
\end{tabular}

Note. The table provides information about the characteristics of 238 open market repurchase programs that were initiated and executed in Finland. Waiting time is the average number of days between the initiation announcement and the first repurchase day. Duration is the average time between the first and the last repurchase day in a repurchase program. Repo days is the average number of repurchase days in a repurchase program.

A total of 85 companies has repurchased share during the time period under study. One repurchase program has been executed by 26 companies, while 13 companies have executed five repurchase programs or more. 
Table 3. Characteristics of open market repurchase programs in Finland

\begin{tabular}{cc}
\hline Programs & Companies \\
\hline 1 & 26 \\
2 & 24 \\
3 & 11 \\
4 & 11 \\
At least 5 & 13 \\
\hline
\end{tabular}

Note. The table provides information about the characteristics of 293 open market repurchase programs that were initiated in Finland during the time period Jan 1998-Dec 2013. Programs is the number of programs initiated by a company during the period, and Companies is the number of companies that initiated the respective number of programs.

\section{Results}

In the first part we look at the stock market reaction to the initiation of a share repurchase program, while we in the second part focus on the stock market reaction to the announcement that the company have actually started to repurchase shares.

\subsection{Stock Market Reaction to the Initiation Announcement of Share Repurchase Programs}

Figure 1 shows the cumulative average abnormal return (CAAR) around the initiation of open market share repurchase programs. We look at a total event window starting 20 trading days before the announcement and ending 20 trading days after the announcement. The sample consists of 262 initiation announcements over the period January 1998 to December 2013(Note 12).

According to the abnormal return shown in Figure 1, the decision to initiate a repurchase program is, on average, preceded by a negative stock market development for the firm's shares. However, the market response is positive to the initiation announcement. In the post-event period, there is a new peak in the excess return after approximately a week caused by the fact that several companies actually starts to repurchase shares after the seven day waiting period.

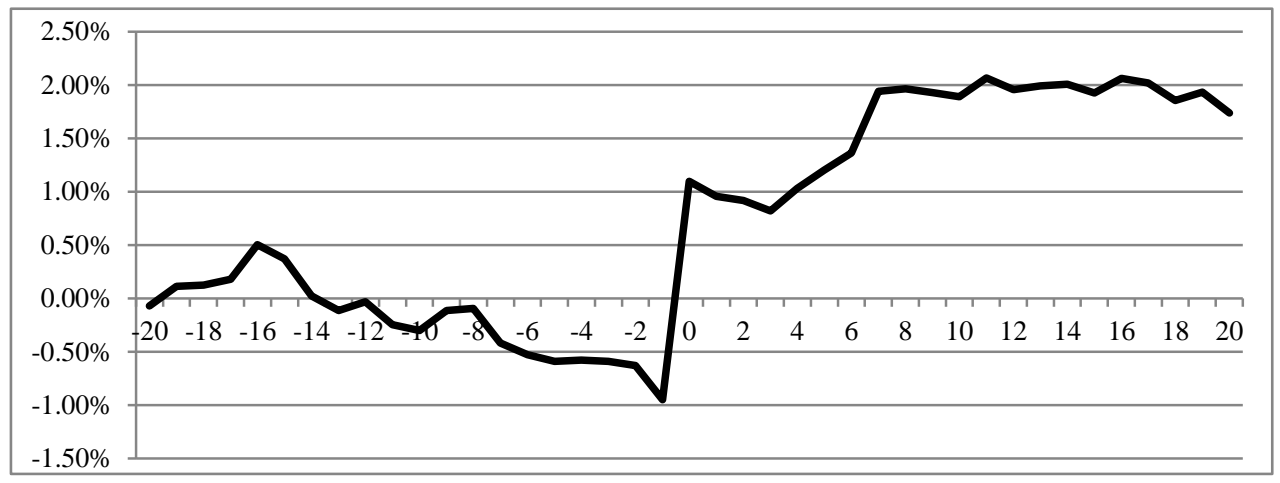

Figure 1. The cumulative abnormal return (CAAR) for initiation announcements

Note. The figure shows the cumulative average abnormal return for an event window of 41 days around the initiation announcement for 262 share repurchase programs in Finland initiated during the time period Jan 1998-Dec 2013. The abnormal return is calculated using the market model. The market return is based on the value-weighted total return index OMX Helsinki. The market model parameters are estimated over a period of 241 days starting 300 days before the announcement.

In Table 4, the cumulative abnormal return is calculated for several event windows around, as well as before and after, the announcement of initiating a share repurchase program. For the total sample there is a significantly positive CAAR for the 41 trading day event window around the initiation announcement of $1.74 \%$. The average event day abnormal return around the initiation announcement is $2.04 \%$ and statistically significant, while the CAAR for the five day event window (from day -2 to +2 ) is $1.51 \%$ and statistically significant. This is in line with most of the studies for other markets reporting a positive stock market reaction to initiation announcements. In the post-event period following the announcement (from day +1 to +10 ), the CAAR is also significantly positive. However, this effect may mainly be caused by the announcement of the actual execution of the repurchases. For the two sub periods (before and after the change in the regulation regarding the amount of own shares that the companies may buy back) the reported results are mainly the same as for the full sample. 
Table 4. Cumulative average abnormal returns (CAARs) for initiation announcements

\begin{tabular}{lcccccc}
\hline & \multicolumn{2}{c}{$1998-2013(262$ obs $)$} & \multicolumn{2}{c}{$1998-2004(121$ obs $)$} & \multicolumn{2}{c}{$2005-2013(141$ obs $)$} \\
\cline { 2 - 7 } Event window & $(\%)$ & $(\mathrm{p}$-value $)$ & $(\%)$ & $(\mathrm{p}$-value $)$ & $(\%)$ & $(\mathrm{p}$-value $)$ \\
\hline$[-20 ;+20]$ & $1.74^{*}$ & 0.065 & 0.61 & 0.404 & $2.88^{* *}$ & 0.012 \\
{$[-10 ;-1]$} & -0.71 & 0.175 & -0.81 & 0.348 & -0.61 & 0.310 \\
{$[-2 ;+2]$} & $1.51^{* * *}$ & 0.000 & $1.20^{*}$ & 0.058 & $1.82^{* * *}$ & 0.000 \\
{$[+1 ;+10]$} & $0.79^{*}$ & 0.095 & 0.67 & 0.943 & 0.91 & 0.146 \\
{$[\mathrm{~T}=0]$} & $2.04^{* * *}$ & 0.000 & $2.13^{* * *}$ & 0.000 & $1.96^{* * *}$ & 0.000 \\
\hline
\end{tabular}

Note. The table reports cumulative average abnormal returns around the initiation announcement for 262 share repurchase programs in Finland initiated during the time period Jan 1998-Dec 2013 over different event windows. The returns are for the full sample and for two sub periods; before (1998-2004) and after (2005-2013) the change in regulations regarding the number of shares a company may repurchase. The expected return is calculated using the market model. The market return is calculated using the value-weighted total return index OMX Helsinki. The market model parameters are estimated over a period of 241 days starting 300 days before the announcement. Statistical significance is denoted by $* / * * / * * *(10 \% / 5 \% / 1 \%)$.

As an additional analysis of the stock market reaction to the announcement, the event day abnormal return (AR) is regressed on different repurchase program characteristics that may affect the market response.

Table 5 shows the results from the regression. The coefficient for the dummy variable indicating that the repurchase program is the first or the second for a company is positive and statistically significant. Hence, the market perceives the information content in these announcements to be more valuable than for companies that frequently uses share repurchases programs (three or more programs).

E.g., Ikenberry et al. (1995) as well as Comment and Jarell (1991) found in their studies that there is a positive correlation between the relative amount of shares sought and the market reaction to the announcement. One explanation for this relationship is that the more shares the company repurchases the stronger the signal of undervaluation. However, for our Finnish sample we do not find a similar relationship. This may be due to the fact that there is a large difference between the fraction of shares sought and the actual fraction of shares the company repurchases. Hence, the market participants do not pay much attention to the announcements regarding the amount of shares sought.

We also include a dummy variable for the change in the regulations regarding the maximum amount of shares that the company may repurchase. However, there does not seem to be any difference in the response to the announcements before and after 2005, since the coefficient for the variable is insignificant.

Table 5. Determinants of the abnormal return (AR)

\begin{tabular}{lcccc}
\hline & \multicolumn{2}{c}{ Initiation } & & \multicolumn{2}{c}{ First day } \\
\hline Dependent variable & coeff. & p-value & coeff. & $p$-value \\
\hline Intercept & $0.012^{*}$ & 0.086 & $0.011^{* *}$ & 0.018 \\
First & $0.014^{* *}$ & 0.034 & $0.011^{*}$ & 0.092 \\
Second & $0.014^{*}$ & 0.055 & 0.003 & 0.613 \\
Sought & -0.009 & 0.918 & $-0.032^{* *}$ & 0.023 \\
Time period & 0.002 & 0.698 & -0.005 & 0.340 \\
AR initiation & & & 0.079 & 0.261 \\
Duration & & & 0.000 & 0.811 \\
Adjusted $\mathrm{R}^{2}$ & 0.023 & & 0.184 & \\
Number of acquisitions & 262 & & 211 & \\
\hline
\end{tabular}

Note. The table reports the results of the OLS regression of the abnormal return for 262 initiation announcements (initiation), and for 211 first day repurchases (first day) of share repurchase programs initiated in Finland during the time period Jan 1998-Dec 2013. First is a dummy variable taking the value 1 if the announcement is for the first share repurchase program the company initiated. Second is a dummy variable taking the value 1 if the announcement is for the second share repurchase program the company initiated. Sought is the fraction of shares the company intended to buy back according to the initiation announcement, Time period is a dummy variable taking the value 1 if the initiation occurred before 2005, AR initiation is the abnormal return on the initiation day, and Duration is the number of days between the initiation announcement and the first day repurchase. All regressions contain White's heteroskedastic-consistent standard errors. Statistical significance is denoted by $* / * * / * * *(10 \% / 5 \% / 1 \%)$.

\subsection{Stock Market Reaction to the Actual Share Repurchases}

In this section we examine how the market reacts to the announcement that a company actually has started to repurchase shares on the open market. If a company has market timing ability, then the company will start to 
repurchase its shares when the shares are undervalued. Other market participants may then trade on this information and, hence, a positive stock market reaction may follow on the announcement that a company repurchases shares.

The information content in the announcement of the first days repurchase, hence, the actual start of the repurchases, should be more unexpected than the following days repurchases. Therefore, we only study the stock market reaction around the day of the first actual repurchase announcement in a repurchase program.

Figure 2 illustrates the CAAR from 20 trading days before to 20 trading days after the first repurchase day in 211 open market share repurchase programs (Note 13). The pre-event excess return seems to be negative, which may indicate that firms possess an ability to identify when the firm is temporarily undervalued. The negative return pattern is reversed approximately one week before the event. This effect is mainly due to the initiation announcements of several companies at that time (due to the waiting period between the initiation and the start of actual repurchases). On the first repurchase day there is a strong positive stock market reaction. These results are in line with the undervaluation hypothesis. However, the observed market reaction may also be driven by an increased demand for the shares, since there is sign of a price reversal in the end of the post-event period.

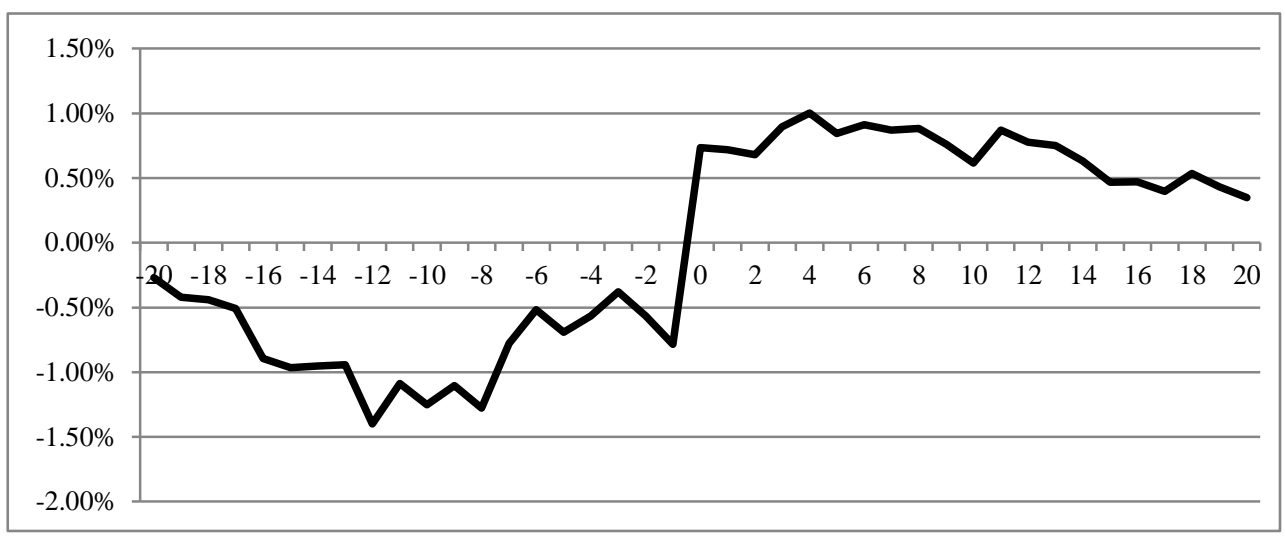

Figure 2. The cumulative abnormal return (CAAR) for first day repurchases

Note. The figure shows the cumulative average abnormal return for an event window of 41 days around the announcement of the first day repurchase for 211 share repurchase programs in Finland initiated during the time period Jan 1998-Dec 2013. The abnormal return is calculated using the market model. The market return is based on the value-weighted total return index OMX Helsinki. The market model parameters are estimated over a period of 241 days starting 300 days before the announcement.

In Table 6, the CAAR is reported for several event windows around, as well as before and after, the first actual repurchase day. The average event day abnormal return around the announcement is $1.52 \%$ and statistically significant, while the CAAR for the five day event window (from day -2 to +2 ) is $1.06 \%$ and statistically significant. In the post-event period (from day +1 to +10 ), the CAAR is negative, however, not statistically significant. For the two sub periods (before and after the change in the regulation regarding the amount of treasury shares the company may hold at any time) the reported results are mainly the same for the event day and for the five day event window as for the full sample.

Table 6. Cumulative average abnormal returns (CAARs) for first day repurchases

\begin{tabular}{lcccccc}
\hline & \multicolumn{2}{c}{$1998-2013(211$ obs $)$} & \multicolumn{2}{c}{$1998-2004(110$ obs $)$} & \multicolumn{2}{c}{$2005-2013(101$ obs $)$} \\
\cline { 2 - 6 } Event window & $(\%)$ & $(\mathrm{p}$-value $)$ & $(\%)$ & $(\mathrm{p}$-value $)$ & $(\%)$ & $(\mathrm{p}$-value $)$ \\
\hline$[-20 ;+20]$ & 0.35 & 0.755 & -1.72 & 0.276 & $3.03^{* *}$ & 0.049 \\
{$[-10 ;-1]$} & 0.30 & 0.629 & -1.24 & 0.206 & $2.63^{* * *}$ & 0.003 \\
{$[-2 ;+2]$} & $1.06^{* * *}$ & 0.006 & $1.20^{* *}$ & 0.036 & 1.01 & 0.139 \\
{$[+1 ;+10]$} & -0.12 & 0.798 & -0.58 & 0.439 & 0.47 & 0.312 \\
{$[\mathrm{~T}=0]$} & $1.52^{* * *}$ & 0.000 & $1.81^{* * *}$ & 0.000 & $1.15^{* * *}$ & 0.001 \\
\hline
\end{tabular}

Note. The table reports cumulative average abnormal returns around the announcement of the first day repurchase for 211 share repurchase programs in Finland initiated during the time period Jan 1998-Dec 2013 over different event windows. The returns are for the full sample and for two sub periods; before (1998-2004) and after (2005-2013) the change in regulations regarding the number of shares a company may repurchase. The expected return is calculated using the market model. The market return is calculated using the value-weighted total return index OMX Helsinki. The market model parameters are estimated over a period of 241 days starting 300 days before the announcement. Statistical significance is denoted by $* / * * / * * * *(10 \% / 5 \% / 1 \%)$. 
As an additional analysis of the stock market reaction to the announcement that the company is actually starting to repurchase shares, the event day abnormal return (AR) is regressed on different repurchase program characteristics that may affect the market response.

Table 5 also reports the results from this regression. The coefficient for the dummy variable indicating that the repurchase program is the first for a company is positive and statistically significant. Hence, the market perceives the information content in these announcements to be more valuable than for companies that more frequently uses share repurchases programs. We also document a statistically significant negative market reaction between the announcement effect and the relative number of shares that the firm intends to buy back in the repurchase program. There is also some indication of a positive correlation between the abnormal return on the initiation day and the first day repurchase announcement effect. However, the coefficient is not statistically significant.

We find no difference in the response to the announcements before and after 2005, neither any effect of the duration (measures in days) between the announcement of the initiation to repurchase and the first actual day of repurchase.

\section{Conclusions}

In this study we examine the stock market reaction to open market share repurchase programs in Finland. The market is strictly regulated regarding both how a company has to announce its intentions to start to repurchase shares and how to inform the market about actual repurchases. As in most countries in the Europe, a share repurchase program by a stock market listed company in Finland has to be approved by the shareholders' meeting. However, unlike most other countries, a company is also required to inform the market when it intends to start buying back its shares, i.e., the company must publically announce the intention to start repurchasing shares. In addition, when the company actually starts to repurchase shares, it also has to inform the market about the daily repurchase activity. This setup enables an analysis of open market repurchase programs and how the market reacts to different announcements regarding these programs.

The purpose of the paper is to look at how the stock market reacts to announcements regarding both the initiation of a program as well as to the actual start of buying back shares. The study utilize data of all open market share repurchase programs from January 1998 to March 2013 by Finnish stock market listed companies.

Regarding the initiation announcements we report an average abnormal event day return of $2.04 \%$. This is in line with, although smaller than, the announcement effect found in prior US studies, but larger than announcement effects reported for European countries. The positive market reaction may be an indication of the market perceiving initiation announcements to be a signal of undervaluation. Interestingly, the abnormal return is larger for companies that initiated a repurchase program for the first or the second time, hence, indicating that the market perceives the information content in these announcements to be more valuable than the information content in announcements from companies that on a regular basis uses repurchase programs.

The market reaction to the announcement that the company has started to buy back shares is positively correlated with the program being the first for a company, and is negatively correlated with the relative number of shares the company aim to buy back. The results indicate that the market perceives that the company has timing ability and, hence, start to buy back shares when they are temporarily undervalued.

\section{References}

Andriosopoulos, D., \& Lasfer, M. (2015). The market valuation of share repurchases in Europe. Journal of Banking \& Finance, 55, 327-339. https://doi.org/10.1016/j.jbankfin.2014.04.017

Brav, A., Graham, J. R., Harvey, C. R., \& Michaely, R. (2005). Payout policy in the 21st century. Journal of Financial Economics, 77, 483-527. https://doi.org/10.1016/j.jfineco.2004.07.004

Brockman, P., \& Chung, D. Y. (2001). Managerial timing and corporate liquidity: Evidence from actual share $\begin{array}{lllll}\text { repurchases. Journal of Financial } & \text { Economics, }\end{array}$ https://doi.org/10.1016/S0304-405X(01)00068-X

Comment, R., \& Jarrell, G. A. (1991). The relative signaling power of Dutch-auction and fixed price self-tender offers and open-market share repurchases. Journal of Finance, 46, 1243-1271. https://doi.org/10.1111/j.1540-6261.1991.tb04617.x

Cook, D., Krigman, L., \& Leach, C. (2004). On the timing and execution of open market repurchases. Review of Financial Studies, 17, 463-498. https://doi.org/10.1093/rfs/hhg028

Dittmar, A. (2000). Why do firms repurchase stocks? Journal of Business, 73, 331-355. 
https://doi.org/10.1086/209646

Dittmar, A., \& Field, L. C. (2015). Can managers time the market? Evidence using repurchase price data. Journal of Financial Economics, 115, 261-282. https://doi.org/10.1016/j.jfineco.2014.09.007

Grullon, G., \& Michaely, R. (2002). Dividends, Share Repurchases and the Substitution Hypothesis. Journal of Finance, 57, 1649-1684. https://doi.org/10.1111/1540-6261.00474

Ikenberry, D., Lakonishik, J., \& Vermaelen, T. (1995). Market Underreaction to Open Market Share Repurchase Programs. Journal of Financial Economics, 39, 181-208. https://doi.org/10.1016/0304-405X(95)00826-Z

Jagannathan, M., Stephens, C., \& Weisbach, M. (2000). Financial flexibility and the choice between dividends and stock repurchases. Journal of Financial Economics, 57, 355-384. https://doi.org/10.1016/S0304-405X(00)00061-1

Kahle, K. (2002). When a buy-back isn't a buyback: Open market repurchases and employee options. Journal of Financial Economics, 63, 235-261. https://doi.org/10.1016/S0304-405X(01)00095-2

Karhunen, J. (2002). Essays on Tender Offers and Share Repurchases. Doctoral Thesis, Helsinki School of Economics.

Lee, C., Ejara, D., \& Gleason, K. (2010). An empirical analysis of European stock repurchases. Journal of Multinational Financial Management, 20, 114-125. https://doi.org/10.1016/j.mulfin.2010.07.002

McNally, W., Smith, B., \& Barnes, T. (2006). The price impact of open market repurchase trades. Journal of Business, Finance and Accounting, 33, 735-752. https://doi.org/10.1111/j.1468-5957.2006.00618.x

Oded, J. (2005). Why do firms announce open-market repurchase programs? Review of Financial Studies, 18, 271-300. https://doi.org/10.1093/rfs/hhh004

Peyer, U., \& Vermaelen, T. (2005). The many facets of privately negotiated share repurchases. Journal of Financial Economics, 75, 361-395. https://doi.org/10.1016/j.jfineco.2004.02.003

Råsbrant, J. (2013). Essays on Share Repurchases and Equity ownership. Doctoral Thesis, Department of Industrial Economics and Management, KTH Stockholm.

Rau, P., \& Vermaelen, T. (2002). Regulation, taxes, and share repurchases in the United Kingdom. Journal of Business, 75, 245-282. https://doi.org/10.1086/338703

Skjeltorp, M., \& Williams, J. (2004). The market impact and timing of open market share repurchases in Norway. Working paper, Bank of Norway.

Stephens, C., \& Weisbach, M. (1998). Actual Share Reaquisitions in Open-Market Repurchase Programs, Journal of Finance, 53, 313-333. https://doi.org/10.1111/0022-1082.115194

Vermaelen, T. (1981). Common stock repurchases and market signaling. Journal of Financial Economics, 9, 139-183. https://doi.org/10.1016/0304-405X(81)90011-8

Zhang, H. (2005). Share price performance following actual share repurchases. Journal of Banking and Finance, 29, 1887-1901. https://doi.org/10.1016/j.jbankfin.2004.06.038

\section{Notes}

Note 1. Brav et al. (2005) report that $86.4 \%$ of all surveyed firms agree or strongly agree with the supposition that the stock price is an important or very important factor to the firm's repurchase decision.

Note 2. See, e.g., Brockman and Chung (2001), Zhang (2002), Cook et al. (2004), McNally et al. (2006), and Dittmar and Fields (2015).

Note 3. See, e.g., Vermaelen (1981), Comment and Jarrell (1991), Ikenberry et al. (1995), Grullon and Michaely (2002), and Peyer and Vermaelen (2005).

Note 4. E.g., Rau and Vermaelen (2002) find an announcement effect of $1.08 \%$ in the UK, while Andriosopulos and Lasfer (2015) finds an announcement effect of 1.68\% in the UK, 2.32\% in Germany and 0,80\% in France.

Note 5. Open market share repurchase programs were allowed in Finland in September 1997, but no repurchase programs were initiated during 1997.

Note 6. Other reasons are, e.g., dividend substitution (Jagannathan, Stephens, \& Weisbach, 2000; Grullon \& Michaely, 2002; capital restructuring (Oded, 2005)), management compensation incentives (Kahle, 2002), excess 
capital hypothesis (Dittmar, 2000) and takeover deterrence hypothesis (Dittmar, 2000).

Note 7. This information is usually disclosed on the same day that the company discloses the financial information for the previous year and other relevant information like, e.g., the Boards suggestion to the shareholders' meeting about the dividend to be paid. Hence, it is impossible to isolate the effect of the share repurchase authorization announcement.

Note 8. The limit was $5 \%$ until year 2005.

Note 9 . The returns are continuously compounded returns.

Note 10. The event day (announcement day) is defined as the day when the information was announced for the first time (or the day after if the announcement occurred after the closing of the trading day or on a non-trading day).

Note 11. The company has to wait at least seven days after the initiation announcement before the actual repurchase may start.

Note 12. We exclude 31 observations due to missing stock market data.

Note 13. We exclude 27 observations due to missing stock market data.

\section{Copyrights}

Copyright for this article is retained by the author(s), with first publication rights granted to the journal.

This is an open-access article distributed under the terms and conditions of the Creative Commons Attribution license (http://creativecommons.org/licenses/by/4.0/). 